\title{
Induction of bronchial hypersensitivity: evidence for a role for prostaglandins
}

\author{
EH WALTERS, RW PARRISH, C BEVAN, AP SMITH \\ From the Asthma Research Unit, Sully Hospital, and Thoracic Unit and MRC Pneumoconiosis Unit, \\ Llandough Hospital, Penarth, South Glamorgan
}

ABSTRACT Bronchial hyper-responsiveness is a particular feature of asthma, but also occurs in normal subjects after a viral upper respiratory tract infection or ozone inhalation. Such stimuli would be expected to result in the release of chemical mediators of inflammation. In this study, the effects of one of these, prostaglandin $\mathrm{F}_{2} \alpha\left(\mathrm{PGF}_{2} \alpha\right)$, on the response of normal subjects to inhaled histamine has been investigated. Nine normal volunteers took 10 inhalations of increasing concentrations of $\mathrm{PGF}_{2} \alpha$ at 15-minute intervals from a Wright's nebuliser under standard conditions until a change in sGaw could be detected. The next lowest serial dilution of $\mathrm{PGF}_{2} \alpha$ was subsequently inhaled by each subject every $15 \mathrm{~min}$ for $90 \mathrm{~min}$ to ensure the absence of a cumulative effect. Inhalation dose-response curves to histamine diphosphate were constructed on two separate occasions using the same standardised technique. Doses were administered every 15 min and sGaw determined five minutes after each. On one occasion each dose of histamine was immediately preceded by the non-active test dose of $\mathrm{PGF}_{2} \alpha$ and on the second by saline as placebo. The study was performed double-blind and in random order. After pretreatment with $\mathrm{PGF}_{2} \alpha$ the histamine dose-response curve was significantly shifted to the left in a parallel fashion $(p<0.001)$. There was a significant decrease in the doses of histamine required to cause a $20 \%$ fall in sGaw $(\mathrm{p}<0.0015)$ but no significant change in the slopes of the dose-response regression lines, indicating that bronchial muscle sensitivity rather than reactivity had been predominantly affected.

Increased responsiveness of bronchial smooth muscle to a wide variety of pharmacological and nonspecific stimuli is one of the most characteristic yet poorly understood features of bronchial asthma. ${ }^{12}$ It also occurs in normal subjects shortly after a viral upper respiratory tract infection, ${ }^{3}$ influenza vaccination, ${ }^{45}$ or ozone inhalation, ${ }^{6}$ and is exaggerated in atopic subjects exposed to allergen in doses insufficient in themselves to affect airways calibre. ${ }^{7}$

Although the participation of cholinergic reflexes is well recognised in the expression of bronchial hyper-responsiveness, ${ }^{3}$ a solely neurological mechanism could not account for all its features. ${ }^{8}$ One explanation could be that biochemical mediators of the inflammatory response might potentiate the response to reflex cholinergic stimulation. Prostaglandins (PGs) have been shown to modify responses to a variety of neurotransmitters ${ }^{9} 10$ and hormones, ${ }^{11}$ and $\mathrm{PGF}_{2} \alpha$ potentiates the contractile response of both

Address for reprint requests: Dr AP Smith, Thoracic Outpatient Department, Llandough Hospital, Penarth, South Glamorgan CF6 1XX. guinea-pig12 13 and human ${ }^{14}$ respiratory smooth muscle to a variety of bronchoconstrictor mediators.

The object of this study was to explore the possibility that $\mathrm{PGF}_{2} \alpha$ in vivo in concentrations too low to influence bronchial muscle tone might increase the responsiveness of the airways to pharmacological stimuli. A preliminary study (Dunlop LS, personal communication) has suggested that this might be the case.

\section{Methods}

Nine normal, non-asthmatic, non-atopic adult volunteers (three women, six men; mean age 34 years, range 23 to 50 years) took part in the study after informed consent had been given. The largest dose of inhaled $\mathrm{PGF}_{2} \alpha$ which had no effect on the airways was determined for each subject and subsequently used as premedication during the construction of an inhalation dose-response curve to histamine.

Drugs were administered via a Wright's nebuliser, 
driven by compressed air at $20 \mathrm{lbs} / \mathrm{sq}$ in and a flow of $10 \mathrm{l} / \mathrm{min}$. A standardised inhalation procedure consisting of 10 slow tidal breaths from FRC was employed throughout.

By diluting $2.5 \mathrm{ml}$ of a $5 \mathrm{mg} / \mathrm{ml}$ solution of the tromethamine salt of $\mathrm{PGF}_{2} \alpha$ (Upjohn Ltd) with normal saline, a range of solutions of $\mathrm{PGF}_{2} \alpha$ was freshly prepared before each experiment. Serial aqueous dilutions of histamine diphosphate from $1 \mathrm{mg} / \mathrm{ml}$ to $25 \mathrm{mg} / \mathrm{ml}$ in five increments were used for construction of the histamine dose-response curves.

Airway responses, measured using a constant volume body plethysmograph, were expressed as changes in specific airways conductance (sGaw) from a baseline defined as the mean of two sets of readings obtained five minutes apart just before the first inhalation. Specific airway conductance was determined at FRC at a flow rate of less than $0.5 \mathrm{l} / \mathrm{s}$ and each recorded value represented the mean of at least six technically satisfactory measurements.

An analysis of variance of all baseline sGaw readings gave a mean intrasubject coefficient of variation of $8 \%$ and indicated that a change of $10 \%$ in the mean of six readings was significant at the 0.05 level. The lowest concentration of $\mathrm{PGF}_{2} \alpha$ resulting in such a change was determined for each subject by inhaling solutions ranging from $0 \cdot 1 \mu \mathrm{g} / \mathrm{ml}$ to $50 \mu \mathrm{g} / \mathrm{ml}$ at $15-\mathrm{min}$ intervals and measuring sGaw at three, five, and 10 minutes after inhalation. The next lowest concentration in the $\mathrm{PGF}_{2} \alpha$ dose range (which had given no measurable change in sGaw) was then used in subsequent experiments. To exclude a cumulative effect this test dose of $\mathrm{PGF}_{2} a$ was inhaled at $15-\mathrm{min}$ intervals for $90 \mathrm{~min}$ with measurement of sGaw at the same time points.

Inhalation dose-response curves to histamine were constructed on two separate occasions at least 48 hours apart, with doses given at $15 \mathrm{~min}$ intervals and sGaw measured five minutes after each. Each dose of histamine was immediately preceded by inhalation of either $\mathrm{PGF}_{2} a$ or normal saline as placebo in random order and under double-blind conditions.

\section{STATISTICAL ANALYSIS}

The occurrence of a significant overall shift in the dose-response curves by $\mathrm{PGF}_{2} \alpha$ premedication was determined by analysis of the mean difference in response per dose of histamine between each set of dose-response curves. For each subject's pair of curves (one premedicated with $\mathrm{PGF}_{2} \alpha$, the other with saline), the difference in response was calculated for each dose of histamine. Any difference in baseline on the two occasions was taken into account by calculating all changes from the mean baseline value. The sum of these differences in response at each dose was then divided by the number of doses tolerated by that subject to give the mean difference per dose $\underset{\sim}{\stackrel{2}{\rightleftharpoons}}$ between the two curves. The significance level for any overall change was given by Student's $t$ test per- $\stackrel{\vec{D}}{+}$ formed on these values obtained from all nineo subjects. Student's $t$ test for paired values was also $\underline{\underline{\underline{\sigma}}}$ performed on the values of baseline sGaw and those $\frac{\bar{c}}{\vec{D}}$ obtained after each dose of histamine.

Dose-response regression lines were constructed from the formula $\mathrm{y}=\mathrm{mx}+\mathrm{c}$ using the doses of $\overrightarrow{0}$ histamine that caused a greater than $15 \%$ fall in sGaw from baseline, such a change being significant $\vec{\omega}$ at the 0.01 level as indicated by the analysis of $\stackrel{\circ}{\circ}$ variance of baseline sGaw readings. From the $\vec{x}$ individual regression lines the dose of histamine that caused a $20 \%$ fall in sGaw (D $20 \%$ ) was calculated $\%$ and this has been taken as an index of bronchial ir "sensitivity" while the slope " $m$ " was taken as an index of bronchial "reactivity." 15 The values for $\mathrm{D}$ 웅 $20 \%$ and the slopes of the regression lines have been analysed by Student's $t$ test for paired values.

\section{Results}

Considerable variation in sensitivity to $\mathrm{PGF}_{2} \alpha$ was found. One subject decreased his sGaw after the $0.5 \mu \mathrm{g} / \mathrm{ml}$ dose and required a test concentration of only $0.25 \mu \mathrm{g} / \mathrm{ml}$ while five others gave no change in $\bar{\partial}$ sGaw after the $50 \mu \mathrm{g} / \mathrm{ml}$ solution, the highest dose used, even on repeated administration.

There was no relationship between either age or $\overrightarrow{\overrightarrow{0}}$ sex and the concentration of $\mathrm{PGF}_{2} \alpha$ required to 3 cause bronchoconstriction.

\section{HISTAMINE DOSE-RESPONSE STUDIES}

There was no significant difference between baseline values of sGaw on the two occasions. Histamine responsiveness varied considerably between subjects $\frac{3}{3}$ and had no relationship to individual sensitivity to $\mathrm{PGF}_{2} \alpha$. Four subjects tolerated the full six doses up to the $25 \mathrm{mg} / \mathrm{ml}$ solution; the studies were terminated because of chest tightness in three subjects $\frac{1}{5}$ after the $15 \mathrm{mg} / \mathrm{ml}$ solution, in one subject after the $\frac{7}{0}$ $20 \mathrm{mg} / \mathrm{ml}$ solution and in one after the $10 \mathrm{mg} / \mathrm{ml}$ solution. The challenges were continued to the same of dose on both occasions in all subjects.

Analysis of the mean differences per dose between $N$ the curves indicated a significant shift to the left $\omega$ $(\mathrm{p}<0.001)$ after $\mathrm{PGF}_{2} a$ premedication. Differences were present $(\mathrm{p}<0.005)$ after $\mathrm{PGF}_{2} \alpha$ at all doses of histamine up to the $20 \mathrm{mg} / \mathrm{ml}$ solution.

The values for D $20 \%$ were significantly decreased $\stackrel{?}{+}$ after PGF $_{2} \alpha(\mathrm{p}<0.0015)$ but there was no significant $\frac{0}{0}$ difference between the slopes of the regression lines. $\stackrel{\mathbb{D}}{\mathbb{D}}$ These results are illustrated in the figure where the $\stackrel{\odot}{\oplus}$ dose-response regression lines between $20 \%$ and $\stackrel{\mathbb{D}}{\circ}$ 
Concentration of histamine $(\mathrm{mg} / \mathrm{ml})$

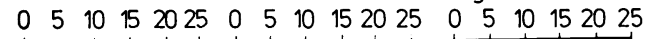

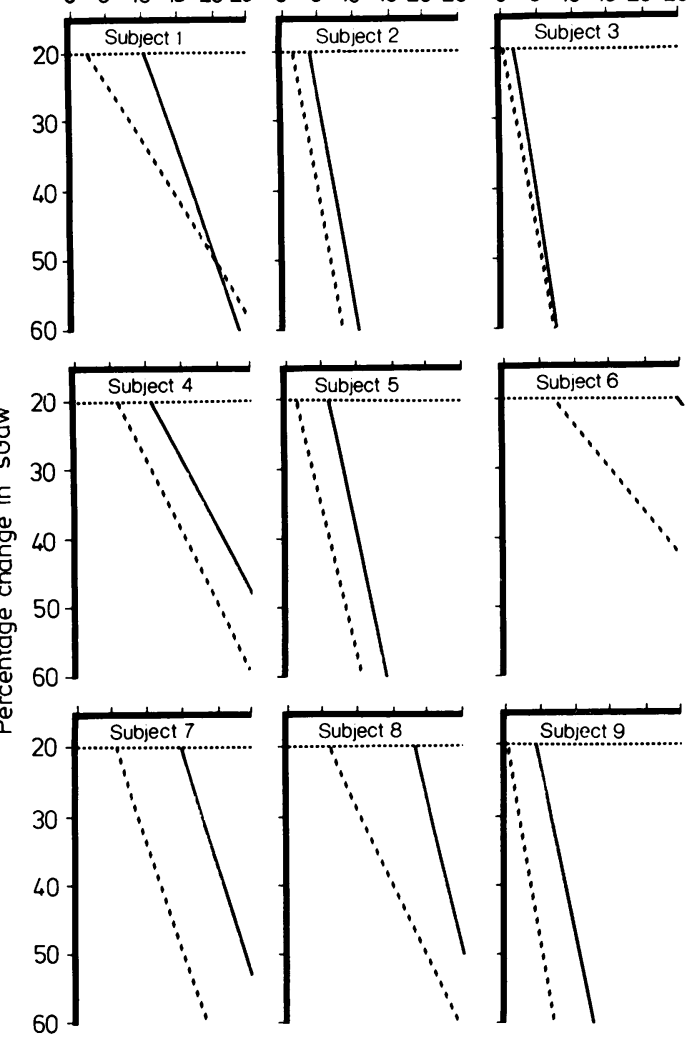

Figure Dose-response regression lines for histamine inhalation between $20 \%$ (D 20\%) and $60 \%$ falls from baseline sGaw, with placebo premedication (-) and $\mathrm{PGF}_{2}$ a premedication (-- - ), for each subject.

$60 \%$ falls from baseline sGaw are shown for each individual.

\section{Discussion}

The increased responsiveness of airway smooth muscle to bronchoconstrictor agents that occurs in asthmatic patients is characterised by both a smaller dose of agonist required to cause a response (sensitivity) and a steeper slope of the dose-response curve (reactivity) compared with normal subjects. ${ }^{15}$ Increased bronchial responsiveness to histamine and methacholine can also be induced in normal subjects after a viral respiratory tract infection, ${ }^{3}$ influenza vaccination, ${ }^{45}$ or after ozone exposure ${ }^{6}$ but in these situations bronchial sensitivity is increased predominantly rather than reactivity.

Many of the circumstances such as allergen ex- posure, local trauma, and infection in the bronchial tree which lead to bronchial hyper-responsiveness are also those in which prostaglandins are generated in the lungs. ${ }^{16}$ In this study we have shown that small doses of $\mathrm{PGF}_{2} \alpha$ insufficient themselves to alter airway calibre demonstrably do potentiate the bronchoconstrictor effect of inhaled histamine and shift the dose-response curve in a parallel fashion to the left indicating that it is bronchial sensitivity which is affected rather than reactivity. ${ }^{15}$ In this in vivo study we were obviously unable to detect any increase in muscle tone that may have occurred without causing a change in sGaw but similar in vitro studies have demonstrated the phenomenon after $\mathrm{PGF}_{2} \alpha$ pretreatment without such an increase in basal tone..$^{12} 14$

A predominant increase in sensitivity would suggest either an increase in agonist concentration in the vicinity of bronchial smooth muscle receptor sites or an increase in activation of the receptor population by a given concentration of agonist, rather than a change in behaviour of the smooth muscle fibres distal to receptor activation. ${ }^{17}$ There are, however, several anatomical sites at which prostaglandins could induce bronchial hypersensitivity to histamine. Vagal irritant receptors, which are known to be activated by histamine, ${ }^{18}$ could have been modified to generate increased neurological activity when stimulated, or synapses in vagally mediated reflex arcs could have been altered to increase transmission. Both of these possibilities would result in a higher concentration of acetylcholine at receptor sites. Alternatively $\mathrm{PGF}_{2} \alpha$ could act to increase either the number or affinity of smooth muscle receptors.

There is some evidence in support of each of these potential sites of action. Nadel ${ }^{19}$ has suggested that bronchial epithelial damage and inflammation results in sensitisation of epithelial irritant receptors and that this is the underlying mechanism in all conditions of bronchial hyper-responsiveness. Prostaglandins would be released by epithelial damage and $\mathrm{PGF}_{2} \alpha$ is known to stimulate vagal sensory receptors in the lung. ${ }^{20}$ Some of the bronchoconstrictor effect of $\mathrm{PGF}_{2} \alpha$ in asthmatic patients can be prevented by atropine 2122 which suggests that $\mathrm{PGF}_{2} \alpha$ activates vagally mediated cholinergic reflex arcs in vivo. It is conceivable, therefore, that $\mathrm{PGF}_{2} \alpha$ could be the mediator of the bronchial epithelial irritant receptor sensitisation postulated by Nadel. ${ }^{19}$

Although there is no direct evidence that $\mathrm{PGF}_{2} \alpha$ has an effect on the synapses of cholinergic reflex arcs, it is also conceivable that $\mathrm{PGF}_{2} \alpha$ could operate to increase activity at these sites to cause an increased effect of any stimulus. Prostaglandins do modify the liberation of noradrenaline by sympathetic nerve stimulation in the rabbit lung ${ }^{9}$ and it has been sug- 
gested that they act as synaptic neuromodulators in the central nervous system possibly by an effect on intraneuronal cyclic nucleotides. ${ }^{10}$

Recent studies, however, have emphasised that post-synaptic changes are more likely to be the cause of hyper-responsiveness of the airways. The ganglionic blocker hexamethonium has been used to dissociate the pre and post ganglionic limbs of vagally-mediated reflex arcs in the lung and has shown that the changes causing hyper-responsiveness are probably at the level of smooth muscle agonist receptors. ${ }^{8}$ In vitro studies on human as well as guinea-pig airway smooth muscle strips have shown that $\mathrm{PGF}_{2} \alpha$ increases the direct effect of constrictor agonists, ${ }^{12} 14$ and it is likely that any similar effect of $P F_{2} \alpha$ in vivo is also situated directly at the level of the smooth muscle fibre.

Cell membrane agonist receptors are not static populations but can change either in numbers or affinity under the influence of their own agonist ${ }^{23}$ or of other agonists acting at separate receptor sites. ${ }^{24-27}$ In the airways $\mathrm{PGF}_{2} \alpha$ could similarly modify either smooth muscle histamine receptors or acetylcholine receptors (activated via vagal reflexes) or both, resulting in the clinical observation of hypersensitivity.

\section{References}

${ }^{1}$ Curry JJ. The action of histamine on the respiratory tract in normal and asthmatic subjects. $J$ Clin Invest 1946; 25:785-91.

${ }^{2}$ Benson MK. Bronchial hyper-reactivity. $\mathrm{Br} J$ Dis Chest 1975;69:227-39.

${ }^{3}$ Empey DW, Laitinen LA, Jacobs L, Gold WM, Nadel JA. Mechanisms of bronchial hyper-reactivity in normal subjects after upper respiratory tract infection. Am Rev Respir Dis 1976;113:131-9.

${ }^{4}$ Laitinen LA, Kava T, Penttinen K, Riski H. Bronchial reactivity following uncomplicated influenza $A$ infection in healthy subjects and in asthmatic patients. Bull Eur Physiopathol Respir 1978;14:195 P.

${ }^{5}$ Laitinen LA, Elkin RB, Empey DW, Jacobs L, Mills J, Gold WM, Nadel JA. Changes in bronchial reactivity after administration of live attenuated influenza virus. Am Rev Respir Dis 1976;113:Abstr. 194.

${ }^{6}$ Golden JA, Nadel JA, Boushey HA. Bronchial hyperirritability in healthy subjects after exposure to ozone. Am Rev Respir Dis 1978;118:287-94.

${ }^{7}$ Hargreave FE, Frith PA, Dolovich M, Morse JC, Newhouse MT. Influence of allergen deposition site on airway response. In: Sadoul P, Milic-Emili J, Simonsson BG, Clark TJH eds. Small airways in health and disease. Amsterdam: Excerpta Medica, 1979:143-51.

${ }^{8}$ Holtzman MJ, Sheller JR, Dimeo M, Nadel JA, Boushey HA. Effect of ganglionic blockade on bronchial reactivity in atopic subjects. Am Rev Respir Dis 1980;
122:17-25.

${ }^{9}$ Mathé AA, Tong EY, Tisher PW, Yen SS. Release of norepinephrine and prostaglandin $E$ from rabbit lung b sympathetic nerve stimulation. Fed Proc 1977;36:982.

${ }^{10}$ Bloom FE. Cyclic nucleotides in central synaptic function Fed Proc 1979;38:2203-7.

${ }^{11}$ Baudouin-Legros M, Meyer P, Worcel M. Effects op prostaglandin inhibitors on angiotensin, oxytocin and prostaglandin $\mathrm{F}_{2} \alpha$ contractile effects on the rat uterus. during the oestrous cycle. Br J Pharmacol 1974;52:393-9 $\vec{\omega}$

${ }^{12}$ Orehek J, Douglas JS, Bouhuys A. Contractile response. of the guinea-pig trachea in vitro: modification by prostaglandin synthesis inhibiting drugs. $J$ Pharmaco $\vec{k}$ Exp Ther 1975;194:554-64.

${ }^{13}$ Kitamura S, Ishihara Y, Yotsumoto H, Sasaki K, Kudoh S. Effect of prostaglandin $\mathrm{F}_{2} \alpha$ on the contractile reir sponses of guinea-pig tracheal tissues induced by various bronchoconstrictors. Jap J Thorac Dis 1978;16:315-9.

${ }^{14}$ Dawson W, Sweatman WJF. Probable role of prosta을 glandins in asthma. Int Arch Allergy Appl Immunol $1975 ;-$ 49:213-6.

${ }^{15}$ Orehek J, Gayrard P, Smith AP, Grimaud C, Charpin Airway response to carbachol in normal and asthmatice subjects. Am Rev Respir Dis 1977;115:937-43.

16 Piper P, Vane J. The release of prostaglandins from lung and other tissue. Ann NY Acad Sci 1971;180:363-85. $\infty$

${ }^{17}$ Boushey HA, Holtzman MJ, Sheller JR, Nadel JA: Bronchial hyper-reactivity. Am Rev Respir Dis 1980 $121: 389-413$.

${ }^{18}$ Sellick H, Widdicombe JG. Stimulation of lung irritant receptors by cigarette smoke, carbon dust and histaming aerosol. J Appl Physiol 1971;31:15-19.

19 Nadel JA. Mechanisms of airways hyperirritability; role of epithelial damage. In: Sadoul P, Milic-Emili J, Simons son BG, Clark TJH eds. Small airways in health an $\bar{B}$ disease. Amsterdam: Excerpta Medica, 1979:68-73.

${ }^{20}$ Coleridge HM, Coleridge JCG, Ginzel KH, Baker DG Banzett RB, Morrison MA. Stimulation of "irritant' receptors and afferent $\mathrm{C}$-fibres in the lungs by prostaglandins. Nature 1976;264:451-3.

${ }^{21}$ Alanko K, Poppius $H$. Anticholinergic blocking o prostaglandin-induced bronchoconstriction. $\mathrm{Br} \mathrm{Med} \mathrm{fर्र}$ $1973 ; 1: 294$

22 Patel KR. Atropine, sodium cromoglycate, and thymox amine in $\mathrm{PGF}_{2} \alpha$-induced bronchoconstriction in extrinsic asthma. $\mathrm{Br}$ Med $J$ 1975;2:360-2.

${ }^{23}$ Lefkowitz RJ. Direct binding studies of adrenergic receptors; biochemical, physiologic, and clinic implica응 tions. Ann Intern Med 1979;91:450-8.

${ }^{24}$ Fleisch JH, Titus E. The prevention of isoprotereno desensitization and isoproterenol reversal. $J$ PharmacoE. Exp Ther 1972;181:425-33.

${ }^{25}$ Szentivanyi A. The radioligand binding approach in the study of lymphocyte adrenoceptors and the constitur tional basis of atopy. $J$ Allergy Clin Immunol 1980 N 65:5-11.

${ }^{26}$ Diekman MA, O'Callaghan P, Nett TM, Niswender GD Effects of prostaglandin $F_{2} \alpha$ on the numbers of $L$ receptors in ovine corpora lutea. Biol Reprod $1978 \frac{\mathrm{C}}{\frac{\mathrm{C}}{\mathrm{D}}}$ 19:1010-3

27 Greenacre JK, Schofield P, Connolly ME. Desensitization ${ }^{+}$ of the $\beta$-adrenoceptor of lymphocytes from normato subjects and asthmatic patients in vitro. $\mathrm{Br} J \mathrm{Clin} \overline{\mathrm{O}}$ Pharmacol $1978 ; 5: 199-206$. 